\title{
Teaching about Water Relations in Plant Cells: An Uneasy Struggle
}

\author{
Lilianna Malińska, ${ }^{\dagger}$ Eliza Rybska, ${ }^{\ddagger}$ Ewa Sobieszczuk-Nowicka, ${ }^{\dagger}$ \\ and Matgorzata Adamiec ${ }^{\dagger *}$ \\ †Department of Plant Physiology and `Department of Nature Education and Conservation, Faculty \\ of Biology, Adam Mickiewicz University in Poznań, 61-614 Poznań, Poland
}

\begin{abstract}
University students often struggle to understand the role of water in plant cells. In particular, osmosis and plasmolysis appear to be challenging topics. This study attempted to identify student difficulties (including misconceptions) concerning osmosis and plasmolysis and examined to what extent the difficulties could be revised during a plant physiology course. A questionnaire was developed to monitor university students' conceptual knowledge before and after a course, and both qualitative and quantitative data were obtained. The data were analyzed using the constant comparison technique and descriptive statistics. Students were found to come to university with many misconceptions that had accumulated during their education. These misconceptions are extremely difficult to change during the traditional course, which comprises lectures and practical exercises. Students' misconceptions originate from commonly used sources such as textbooks, which are perceived as being reliable. Effective teaching of water relations in plant cells could include such didactic methods as "questioning the author," which allow teachers to monitor students' knowledge and help students acquire a more scientific understanding of key concepts.
\end{abstract}

\section{INTRODUCTION}

Misconceptions and Conceptual Change: General Concept

According to the constructivist view of learning, preconceptions play a crucial and productive role in the acquisition of expertise. Students' prior notions serve as a resource for cognitive growth within a complex system of knowledge (Smith et al., 1994). Over the past three decades, students' misconceptions in a wide range of subject areas have been identified and categorized (e.g., see Pfundt and Duit, 2004). These personal conceptions are often deeply rooted and instruction-resistant obstacles to the acquisition of scientific concepts, and they may remain even after instruction (Dikmenli, 2010). It is well documented that such misconceptions are resistant to change (e.g., Driver 1989; Mintzes et al., 1998, 2005). Misunderstandings may have been present before any teaching and can be found even after teaching has taken place (Özmen, 2004). It has also been reported that such misconceptions may be held by teachers or presented in textbooks (Wandersee et al., 1994; Bahar, 2003; Dikmenli, 2010).

The process of changing misconceptions to correct scientific conceptions is called conceptual change. Chi and Roscoe (2002) proposed that misconceptions should be named as "miscategorization of concepts" and the process of conceptual change as "conceptual reorganization," since it needs an ontological shift from one "ontological category" to another. They point out that this reorganization is difficult or challenging when students are unaware of their misconceptions and/or lack the alternative category into which they should reassign them. However, diagnosing students' conceptions and misconceptions is a prerequisite to developing lessons that result in a conceptual change (Odom, 1995).
Nancy Pelaez, Monitoring Editor

Submitted May 22, 2015; Revised June 3, 2016; Accepted June 3, 2016

CBE Life Sci Educ December 1, 2016 15:ar78 DOI:10.1187/cbe.15-05-0113

*Address correspondence to: Małgorzata Adamiec (msolin@amu.edu.pl).

(c) 2016 L. Malińska et al. CBE-Life Sciences Education @ 2016 The American Society for Cell Biology. This article is distributed by The American Society for Cell Biology under license from the author(s). It is available to the public under an Attribution-Noncommercial-Share Alike 3.0 Unported Creative Commons License (http://creativecommons.org/licenses/ by-nc-sa/3.0).

"ASCB $®$ " and "The American Society for Cell Biology $\bigotimes^{\prime \prime}$ are registered trademarks of The American Society for Cell Biology. 


\section{The Issue of Water Relations in Plant Cells}

Water relations in plant cells are among the most important topics in university courses on plant physiology. Learning about mechanisms underlying water balance in plant cells is dependent on understanding concepts such as osmosis and diffusion. Diffusion is defined as the random, thermal movement of molecules in which a net flow of matter moves along a concentration gradient (from an area of higher concentration toward an area of lower concentration; Friedler et al., 1987; Freedman and Sperelakis, 2012). Osmosis is the flow of a solvent across a semipermeable membrane from a region of lower to higher solute concentration (Kramer and Myers, 2012). The osmotic flow is governed by water potential, which in a simplified form may be described as the sum of pressure potential and solute potential, wherein pressure potential is equal to hydrostatic pressure (Kramer and Myers, 2013). The water uptake and release in the cell is based on osmosis. Although the water transport through the cell membranes also occurs directly across the phospholipid bilayer, rapid translocation of large water volumes is carried out by aquaporinsmajor membrane intrinsic proteins, called also "water channels" (Johansson et al., 2000). In walled cells, osmotic flow of water out of the cell leads to a phenomenon called "plasmolysis," in which the cytoplasm shrivels and the plasma membrane pulls away from the cell wall (Minorsky, 2008).

\section{Misconceptions around Water Relations in Plant Cells}

Our observations, based on our experience of teaching university students over many years, suggest that understanding mechanisms underlying the water relations in plant cells remains extremely difficult. These difficulties may result from the fact that this topic is related to the processes of diffusion and osmosis, which have been reported as some of the hardest biological concepts to understand (Odom, 1995; Sanger et al., 2001; She, 2004). It is thought that problems with understanding diffusion and osmosis are the result of a number of causes: a confusion regarding vernacular and scientific usage of such terms as pressure, concentration, and quantity; misunderstanding technical concepts such as solution, semipermeability, and molecular and net movement; and insufficient abilities in terms of formal reasoning, visualization, and thinking at the molecular level (Odom and Barrow, 1995; She, 2004).

These difficulties can result in students' knowledge concerning diffusion and osmosis being fragmentary and burdened with a number of misconceptions. Inadequate appreciation of the random molecular movement concept results in a common belief that diffusion and osmosis occur because molecules "want" or "aim" to reach equal concentrations in the whole system (Friedler et al., 1987; Odom and Kelly, 2001; Meir et al., 2005). Other widespread misconceptions include 1) a conviction that the movement of particles takes place only until concentrations between environments equalize (Odom and Kelly, 2001; Meir et al., 2005; Tomažič and Vidic, 2012) and 2) a view that diffusion speed is irrespective of the concentration difference (Meir et al., 2005).

Many students also have problems comparing concentrations and understanding the "equal concentration" term, which students often equate with meaning an equal quantity of water molecules on each side of the semipermeable membrane. There are also beliefs that increased molecular density is unrelated to pressure or volume; a view that solutes differing in the size of particles would have differing effects on osmosis; a conviction that both processes will not continue after the cell's death; and, finally, a confusion between the concepts of diffusion and osmosis (Meir et al., 2005; Tomažič and Vidic, 2012).

To understand basic mechanisms determining water balance in plant cells, it is necessary not only to understand diffusion and osmosis accurately but also to know about plasmolysis and be aware of the relationships between all three processes. Despite the fact that educational difficulties in understanding water relations may, to a large extent, be connected with problems arising from misunderstanding diffusion and osmosis, other factors disturbing the didactic process cannot be excluded.

\section{Content Analysis and Textbooks as the Sources of Misconceptions}

Some of the most important sources of students' scientific knowledge are textbooks, which are often the major source of reference in biology lessons (Edling, 2006). Content analysis reports indicate that textbooks can contain serious factual errors (Cho et al., 1985; Dikmenli and Cardak, 2004; Kose and Hasenekoglu, 2011).

Content analysis is a useful research tool widely applied in the social sciences "for making valid and replicable interferences from data to their context" (Krippendorff, 1989). To investigate data within a specific content, the method requires a common analytical procedure, including formulating research questions, selecting samples, defining applied categories, outlining and implementing the coding process, and analyzing the results (Kaid, 1989; Krippendorff, 1989). According to Hsieh and Shannon (2005), the success of content analysis depends greatly on the coding. Therefore, coding was the last step in our research and addressed the question "Are textbooks a source of misconceptions about osmosis for Polish university students?"

\section{The Aims of the Study}

The first aim of our study was to identify and determine the prevalence of university biology students' misconceptions concerning osmosis and plasmolysis. Next, we investigated whether and to what extent those misconceptions are subject to conceptual change in the course of discussing osmosis and plasmolysis during a plant physiology course. The prevalence of some misconceptions, a subset of which are more common than the scientific point of view among students, had prompted us to suspect that that they have their roots in commonly available and seemingly reliable sources of knowledge. Research indicates that the major source of reference for students during biology lessons is textbooks (Edling, 2006), which have already been shown to perpetuate some misconceptions (Cho et al., 1985; Dikmenli and Cardak, 2004; Kose and Hasenekoglu, 2011). Previous research prompted us to analyze whether high school and university textbook definitions of osmosis and plasmolysis contribute to the dissemination and preservation of the misconceptions concerning these phenomena.

\section{METHODS}

\section{Questionnaire Design}

We developed a questionnaire to identify problems related to understanding the regulation of water balance in plant cells. The questions were based on previously gathered data obtained 
from informal interviews with biology high school and university teachers, class observations, student tests and examinations from previous years, and previous research (e.g., She, 2004; Meir et al., 2005; Tomažič and Vidic, 2012). The data allowed us to identify areas that caused particular difficulties for students. Having identified a number of "difficult" topics and concepts, we designed a pilot version of the questionnaire that included open, semiopen and closed questions. The open questions were generally applied to obtain in-depth, qualitative data concerning student understanding of osmosis and plasmolysis. The closed and semiopen questions were applied to obtain quantitative data about the stage of education at which the concepts had been taught and the educational methods that had been used to introduce students to them.

The content validity of the questionnaire was established by two experienced biology academics. Next, the pilot study was completed by 32 biology students at Adam Mickiewicz University, and the initial version of the questionnaire was revised. For example, some of the open questions were clarified by changing them to semiopen or closed items.

The final version of questionnaire consisted of 12 questions (or tasks), of which four were closed, two semiopen, and the other six open (see questionnaire in the Supplemental Material). Four of the questions identified the education level at which students became familiar with the concepts of diffusion, osmosis, and plasmolysis and the didactic methods used to teach them. The remaining eight questions concerned students' knowledge of definitions of diffusion, osmosis, plasmolysis, and water potential; their ability to use tonicity and water potential concepts as "forces" that determine net water flow in a certain direction; their ability to distinguish between osmosis and diffusion; their understanding of the relationship between osmosis and plasmolysis and the role of aquaporins in both processes; and, finally, their awareness of the nature of osmosis (physical) and plasmolysis (biological).

Students were asked to label their questionnaires with the numbers of their student groups and the last four digits of their personal identity numbers according to the scheme $\mathrm{G}$ (group number) and PIN last four numbers (e.g., 5355). Additionally, at the beginning of each respondent's codes, we added the research stage number (S1 or S2).

\section{Participants}

All the participants were students enrolled in the plant physiology course in 2014. The research was carried out in two stages. First, the diagnostic questionnaire was completed by a group of 105 second-year biology students before starting a course on plant physiology comprising lectures and practical exercises in the field of water relations in plant cells (stage 1). Second, the same group of students answered the diagnostic questionnaire after the teaching sequence (stage 2). The size of the participant group at this stage was 98 .

\section{Structure of Plant Physiology Course}

The whole plant physiology course comprised 30 hours of lectures, 10 hours of seminars, and 60 hours of practical exercises. The concepts of diffusion, osmosis, and plasmolysis were discussed directly during a lecture and 9 hours of practical exercises (two sessions of 4.5 hours each). During every practical exercise, students in groups of four performed four or five experiments. For each experiment, the students were obliged to write a report containing their results and conclusions. The conclusions were discussed with the teacher and, if necessary, corrected. One week after the practical exercises, the diagnostic questionnaire for stage 2 was completed.

\section{Questionnaire Analysis}

The questionnaire analysis method was based on Creswell (1994). First, the data were organized and prepared for analysis. We then read through all the questionnaires and letter-coded the data; the letter-coded data were used to develop categories (for details, see answer key in the Supplemental Material). The data were interpreted and described on the basis of the created categories. We applied the constant comparison technique when coding the data (Glaser and Strauss, 1967). In this process, codes and categories were repeatedly refined.

Questionnaires in which respondents indicated they were not familiar with a given concept (tasks 1 and 7) were excluded from the analysis. To ensure interrater reliability, two university biology teachers participated in the process of creating the coding system, and they independently analyzed the questionnaires. The initial coding agreement rate was $92 \%$, and any disagreements were settled by discussion. Analysis of the incidence of each category allowed an indication of the most common misconceptions. Tasks with no or illegible answers were excluded from the analysis. For the analysis of the closed questionnaire questions, a descriptive statistic method was applied. The chi-square test (Stangroom, 2014a) was applied to determine the relationship between the frequency of incorrect answers to particular questions at different stages of the research (1 or 2; Huck, 2008). To investigate the significance of changed answers to the same questions and misconceptions, we applied the z-test for two-population proportions with the use of $z$-test calculator for two-population proportions (Bluman, 2009; Stangroom, 2014b). Tasks with illegible answers were excluded from the analysis.

\section{Qualitative Analysis of Textbooks}

We used content analysis to identify textbook definitions of osmosis and plasmolysis that may promote misconceptions. This method was also used to determine whether and how aquaporins are described. The analysis was performed with regard to 13 of the most commonly used textbooks in Poland (five at the high school level and eight at the university level). Literature-based categories were then set (e.g., Meir et al., 2005; Rundgren et al., 2010; Kramer and Myers, 2012) and used in the analysis. The following categories of osmosis definitions emerged: 1 ) not mentioning the presence of the semipermeable membrane; 2) indicating that particles pass through the biological membrane; 3) limiting the osmotic process to water molecules or liquids only; 4) indicating that osmosis is a case of diffusion; and 5) indicating tonicity or solute concentration gradient as the driving force for osmosis. The definition of plasmolysis provided by the textbooks was also analyzed using two criteria: 1) Is the definition of plasmolysis present in the given textbook or not? 2) Does the definition or description of the process indicate that plasmolysis results from osmotic flow of water from the cell? The analysis of the aquaporin definition was conducted in four categories: 1) indication that aquaporins participate in water transport; 2) indication that aquaporins are 
present in the cell membrane; 3) indication that aquaporins are proteins; and 4) indication that aquaporins form channels.

\section{RESULTS \\ Stage 1: Students' Knowledge and Understanding of Concepts Related to Water Balance in Plant Cells before the Plant Physiology Course}

All participants stated that they were familiar with osmosis, and the vast majority claimed they had learned about it at an earlier (nonuniversity) stage of education (questionnaire, task 1). Most students (90\%, $n=105)$ also claimed they were familiar with plasmolysis. The vast majority of students who claimed to be familiar with plasmolysis reported that the subject had been introduced at previous (nonuniversity) stages of education (90\%; questionnaire, task 7). Respondents reported that their school classes concerning osmosis and plasmolysis had been mainly theoretical. Among other didactic methods used at school, students mentioned experiments illustrating osmosis (19\%) or plasmolysis $(19 \%)$ and a film or animation presenting osmosis $(20 \%)$ or plasmolysis (6\%; questionnaire, tasks 2 and 8).

Despite the fact that all students stated they were familiar with osmosis, only $11 \%$ of them were able to define the process correctly as permeation of water/solute/dispersed phase through the semipermeable membrane (Table 1, task 3). The most frequent mistakes included not mentioning the presence of the semipermeable membrane (66\%), for example, "osmosis is penetration of the solution from higher concentration to lower concentration" (Student S1G2.2280), and confusion concerning kinds of particles passing through the membrane (57\%), for example, "salts or other compounds dissolved in water migrate from the points of higher concentration to a place of lower con- centration through the barrier" (Student S1G4.2806). Another widespread misconception (54\%) was the belief that osmosis was a biological process that occurred only in cells of living organisms, that is, animal cells, plant cells, or both, but not in artificial systems (Table 2). This misconception appeared even if the student was able to define the osmotic process (Table 3, task 3/9a).

The vast majority of students were unable to indicate the difference between diffusion and osmosis. Only 7\% explained that osmosis occurred in the presence of the semipermeable membrane, while in answers related to the process of diffusion, the membrane was usually absent (Table 1, task 5). Knowledge of the difference between diffusion and osmosis and the ability to define osmosis also varied (Table 3 , task 3/5). The most widespread misconception concerning the difference between both processes was the belief that osmosis referred only to water $(27 \%)$ and diffusion to other molecules or only to gases. The difference between both processes was often related to the concentration gradient, for example, "diffusion takes place down the concentration gradient, and osmosis not" (Student S1G3.3546), or the involvement of carriers, for example, "diffusion can be facilitated" (Student S1G2.6425; Table 2).

None of the students was able to give the correct definition of water potential (Table 1, task 6); however, $25 \%$ of them could indicate correctly the direction of the net movement of water molecules between solutions with differing water potentials (Table 1 , task $4 \mathrm{~b})$. The most frequent mistake (25\%) was to confuse the type of particles moving through the membrane, for example, both water and solutes. Another frequent (14\%) error concerned an incorrect direction of net water flow (Table 2). Students were generally familiar with the concept of tonicity, since a third of them correctly identified the direction

TABLE 1. The significance of changes in percentage of correct answers before (stage 1) and after (stage 2) plant physiology course according the $z$-test for two-population proportions

\begin{tabular}{|c|c|c|c|c|c|c|}
\hline Task number & Task description & $\begin{array}{l}\% \text { of correct answer } \\
\text { in stage } 1\end{array}$ & $\begin{array}{l}\% \text { of correct answer } \\
\text { in stage } 2\end{array}$ & $\begin{array}{l}z \text {-Score } \\
\text { value }\end{array}$ & $p$ Value & $\begin{array}{c}\text { Significance } \\
(\alpha=0.05)\end{array}$ \\
\hline \multicolumn{2}{|c|}{ The number of questionnaires included in the analysis } & 105 & 98 & & & \\
\hline 3 & Definition of osmosis & 11 & 32 & -3.70 & 0.00 & Significant \\
\hline \multicolumn{2}{|c|}{ The number of questionnaires included in the analysis } & 83 & 88 & & & \\
\hline $4 a$ & Particle movement in tonicity context & 34 & 39 & -0.72 & 0.47 & Not significant \\
\hline $4 \mathrm{~b}$ & $\begin{array}{l}\text { Particle movement in water potential } \\
\text { context }\end{array}$ & 25 & 54 & -4.30 & 0.00 & Significant \\
\hline \multicolumn{2}{|c|}{ The number of questionnaires included in the analysis } & 105 & 98 & & & \\
\hline 5 & $\begin{array}{l}\text { Difference between diffusion and } \\
\text { osmosis }\end{array}$ & 7 & 22 & -3.09 & 0.00 & Significant \\
\hline 6 & Definition of water potential & 0 & 7 & -2.69 & 0.01 & Significant \\
\hline \multicolumn{2}{|c|}{ The number of questionnaires included in the analysis } & 95 & 98 & & & \\
\hline $9 \mathrm{a}$ & Structures where osmosis occurs & 32 & 42 & -1.58 & 0.11 & Not significant \\
\hline $9 \mathrm{~b}$ & Structures where plasmolysis occurs & 54 & 66 & -1.69 & 0.09 & Not significant \\
\hline \multicolumn{2}{|c|}{ The number of questionnaires included in the analysis } & 74 & 92 & & & \\
\hline 10 & $\begin{array}{l}\text { Cell behavior in solutions with water } \\
\text { potential lower/higher then water } \\
\text { potential of cell interior }\end{array}$ & 30 & 50 & -2.90 & 0.00 & Significant \\
\hline \multicolumn{2}{|c|}{ The number of questionnaires included in the analysis } & 95 & 98 & & & \\
\hline 11 & $\begin{array}{l}\text { Role of aquaporins in osmosis and } \\
\text { plasmolysis }\end{array}$ & 60 & 55 & 0.48 & 0.48 & Not significant \\
\hline 12 & Osmosis-plasmolysis relationship & 16 & 32 & -3.09 & 0.00 & Significant \\
\hline
\end{tabular}

The table does not include questions 1, 2, 7, and 8. The excluded questions were designed to determine whether students were familiar with the concepts of diffusion and osmosis and to determine teaching methods used for this purpose. Tasks with illegible answers were excluded from the analysis. 
TABLE 2. The identified misconceptions and significance of changes in their distribution before (stage 1) and after (stage 2) plant physiology course

\begin{tabular}{|c|c|c|c|c|c|}
\hline \multirow{4}{*}{$\begin{array}{l}\text { Definition of osmosis } \\
\text { Number of answers incl }\end{array}$} & Stage 1 & Stage 2 & & & \multirow[b]{4}{*}{ Result } \\
\hline & 101 & 98 & & & \\
\hline & & & \multicolumn{2}{|c|}{$\begin{array}{l}\text { Significance of change in } \\
\text { frequency }(\alpha=0.05)\end{array}$} & \\
\hline & \multicolumn{2}{|c|}{ Frequency (\%) } & $z$-Score & $p$ Value & \\
\hline Not mentioning the presence of a semipermeable membrane & 66 & 50 & 2.31 & 0.02 & Significant \\
\hline $\begin{array}{l}\text { Confusion concerning kind of particles passing through the } \\
\text { membrane }\end{array}$ & 57 & 35 & 3.14 & 0.00 & Significant \\
\hline \multicolumn{6}{|l|}{ Particle movement in tonicity context } \\
\hline Number of answers included in the analysis & 77 & 80 & & & \\
\hline Confusion in type of particles moving through the membrane & 25 & 20 & 0.85 & 0.40 & Not significant \\
\hline Improper direction of net water flow & 9 & 18 & -1.88 & 0.06 & Not significant \\
\hline \multicolumn{6}{|l|}{ Particle movement in water potential context } \\
\hline Number of answers included in the analysis & 70 & 79 & & & \\
\hline Confusion in type of particles moving through the membrane & 25 & 16 & 1.58 & 0.11 & Not significant \\
\hline Improper direction of water flow & 14 & 6 & 1.89 & 0.06 & Not significant \\
\hline \multicolumn{6}{|l|}{ Difference between diffusion and osmosis } \\
\hline Number of answers included in the analysis & 96 & 98 & & & \\
\hline $\begin{array}{l}\text { Osmosis refers only to the water and diffusion to other } \\
\text { molecules/gasses }\end{array}$ & 27 & 22 & 0.83 & 0.40 & Not significant \\
\hline $\begin{array}{l}\text { Difference is in direction of flow in relation the concentration } \\
\text { gradient }\end{array}$ & 14 & 1 & 3.47 & 0.00 & Significant \\
\hline Difference is in involvement of carriers & 14 & 19 & -0.96 & 0.34 & Not significant \\
\hline \multicolumn{6}{|l|}{ Structures where osmosis occurs } \\
\hline Number of answers included in the analysis & 95 & 98 & & & \\
\hline $\begin{array}{l}\text { Osmosis is a biological process that occurs only in cells } \\
\text { of living organisms (animal cells, plant cells or both } \\
\text { types of the cells, but not in artificial systems) }\end{array}$ & 54 & 41 & 1.85 & 0.06 & Not significant \\
\hline \multicolumn{6}{|l|}{ Structures where plasmolysis occurs } \\
\hline Number of answers included in the analysis & 95 & 98 & & & \\
\hline Plasmolysis occurs in animal cells & 28 & 14 & 2.44 & 0.01 & Significant \\
\hline Plasmolysis occurs in artificial structures & 18 & 21 & -0.54 & 0.60 & Not significant \\
\hline \multicolumn{6}{|l|}{$\begin{array}{l}\text { Cell behavior in solutions with water potential lower/ } \\
\text { higher then water potential of cell interior }\end{array}$} \\
\hline Number of answers included in the analysis & 55 & 85 & & & \\
\hline Confusion with direction water flow & 65 & 39 & 3.71 & 0.00 & Significant \\
\hline No changes in the cell shape indicated & 60 & 41 & 2.71 & 0.01 & Significant \\
\hline \multicolumn{6}{|l|}{ Osmosis-plasmolysis relationship } \\
\hline Number of answers included in the analysis & 54 & 65 & & & \\
\hline They relate to migration (transport) of water & 10 & 7 & 0.76 & 0.45 & Not significant \\
\hline Operate on the same principle & 6 & 8 & -0.56 & 0.58 & Not significant \\
\hline
\end{tabular}

Tasks with no or illegible answers were excluded from the analysis.

of net water flow when concepts of "hypertonic" and "hypotonic" solutions were applied (Table 1, task 4a). The direction of net water flow in this context was incorrectly indicated by only $9 \%$ of the students, and as in the case of water potential, the most frequent mistakes related to the kind of molecules passing through the membrane (25\%).

More than half of the respondents (54\%) correctly identified the plant cell as an example of a structure in which plasmolysis could be observed (Table 1, task 9a). The majority of students $(60 \%)$ were also familiar with the concept of aquaporins and their function in the cell membrane (Table 1, task 11). However, only $16 \%$ could define plasmolysis accurately as being caused by osmotic water flow from the cell (Table 1, task 12).
Among the most frequent incorrect answers concerning associations between both processes were statements about migration (transport) of water (10\%), for example, "both processes are related to water transport" (student: S1.G1.5355), and operating principle (6\%), for example, "both processes are energy independent” (student: S1.G3.6320; Table 2).

According to the chi-square test analysis, being able to define osmosis correctly and being able to identify the relationship between osmosis and plasmolysis were independent. Similarly, we did not observe any association between the ability to indicate structures where osmosis or plasmolysis occurred and the ability to correctly identify the relationship between osmosis and plasmolysis (Table 3, task $9 \mathrm{a} / 12$ and $9 \mathrm{~b} / 12$ ). Only 30\% 


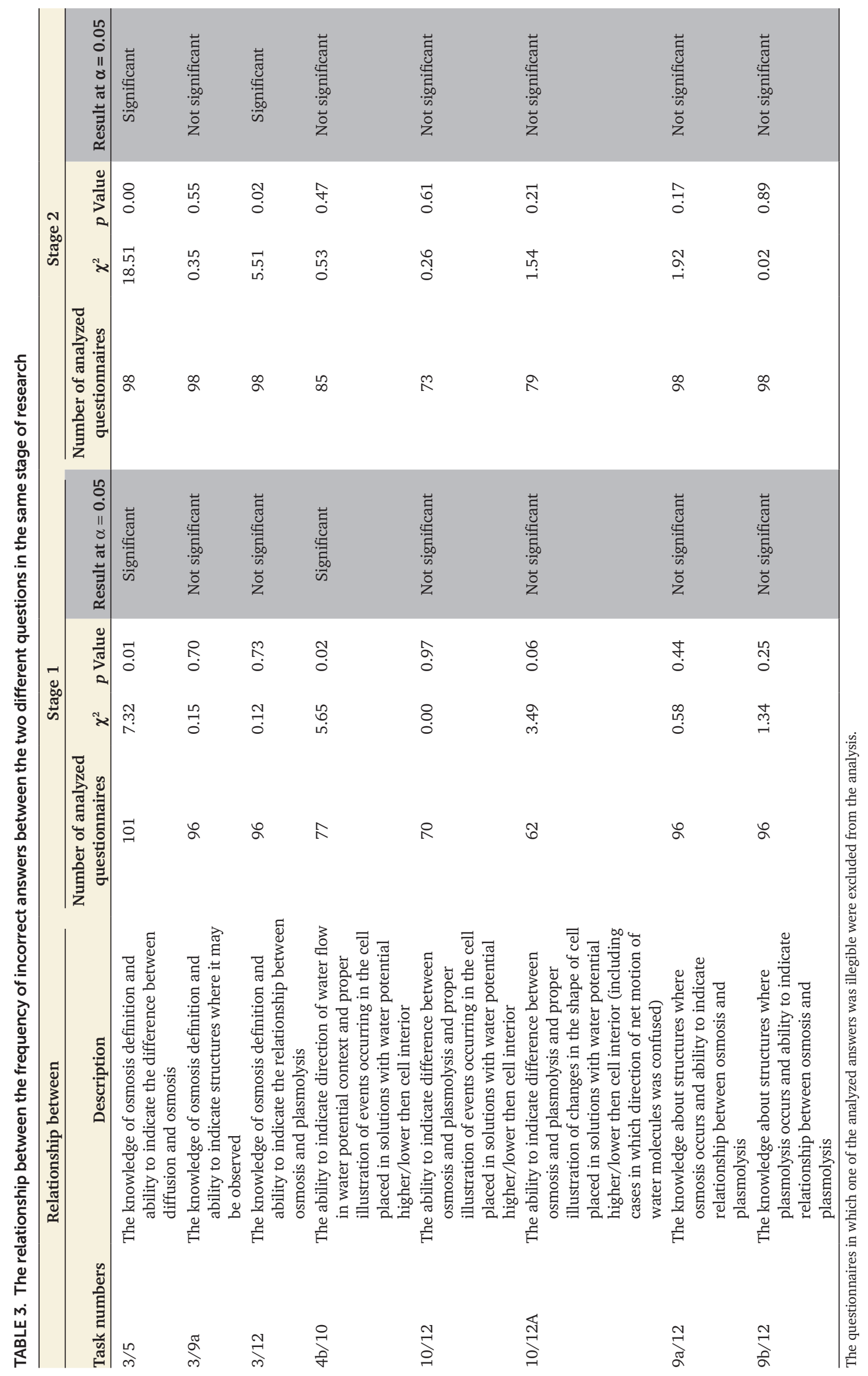


of the participants were able to accurately describe the behavior of a cell placed in solutions that had higher or lower water potential than the water potential of the cell itself (Table 1, task 10; Figure 1A). Being able to illustrate cells in solutions differing in water potential, such as changes in cell shape, and knowledge of associations between osmosis and plasmolysis were dependent. The most frequent mistake was to confuse the direction of the net motion of water molecules (65\%; Figure 1C), which, according to the chi-square test analysis, resulted from a lack of ability to apply the water potential concept in practice (Table 3 , task $4 \mathrm{~b} / 10)$. The majority of the students (60\%) did not include any changes in the cell shape in their drawings (Figure 1B). The awareness of the changes in the cell shape and the ability to indicate differences between osmosis and plasmolysis were independent (Table 3, task 10/12A). The average number of correct answers to the questionnaire items during the first stage of the research was $27 \%$.

\section{Stage 2: Students' Knowledge and Understanding of Concepts Related to Water Balance in Plant Cells after the Plant Physiology Course}

After the plant physiology course, the average number of correct answers increased from 27 to $42 \%$. Although the result was
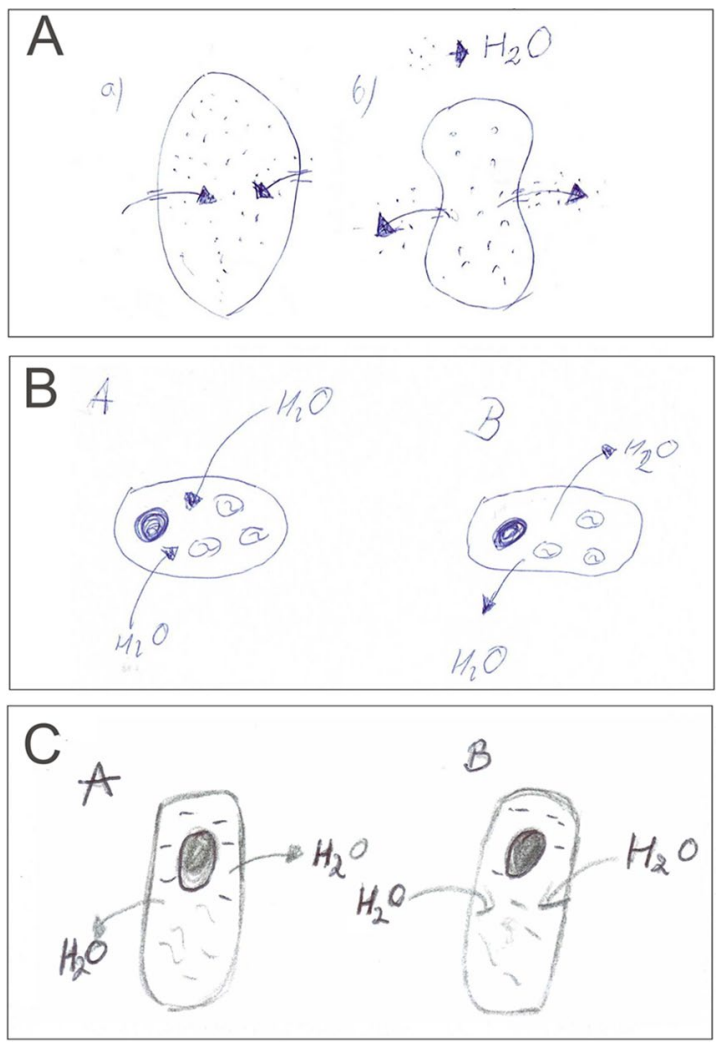

FIGURE 1. Examples of students' drawings in response to task 10. (A) An example of proper answer (Student S1G3.7515). Direction of water molecules net flow is indicated correctly and changes in the cell shape were taken into account. (B) An example of answer in which, although the direction of water flow is proper, there is no indication of changes in cell shape (Student S1G2.2516). (C) The direction of water flow is incorrect, and there are no changes in the cell shape (Student S1G2.0518). statistically significant (z-score: $2.2863, p$ value is 0.02202 , $p<0.05)$, it was still unsatisfactory, since it indicated that the topic of water relations in plants remained elusive for the majority of students even after lectures and practical activities. The largest increase in correct answers (from 25\% in stage 1 to $54 \%$ in stage 2) concerned the direction of water flow between solutions differing in water potential (Table 1, task 4b). This gain is understandable, because water relations in plant cells were discussed during the course in the context of water potential, not tonicity. The knowledge of the "water potential" definition also increased significantly (Table 1, task 6), even though the term still remained rather obscure for students, with only $7 \%$ able to define it correctly as the amount of Gibb's free energy (or useful work) that 1 mole of water contributed to the system. Osmosis was also much better understood (an increase from 11\% correct in stage 1 to $32 \%$ in stage 2; Table 1 , task 3). Generally, students were considerably less confused after the course about the type of particles passing through the membrane and were more aware of the participation of the semipermeable membrane in osmosis (Table 2). Although the number of correct osmosis definitions was much higher, almost two-thirds (68\%) of respondents were still unable to give the correct answer.

The occurrence of misconceptions concerning the definition of osmosis remained unchanged. Students perceived it as a biological process (41\%) and indicated that it occurs in living cells but not in artificial systems (Table 2). Their knowledge of the definition of osmosis and their ability to indicate structures where osmosis may be observed remained unrelated (Table 3, task 3/9a). A significant increase was observed in the percentage of correct answers about the difference between diffusion and osmosis (Table 1, task 5). Students' prior belief that the difference was related to the concentration gradient disappeared (Table 2). However, answers linking the difference between both phenomena with the carriers' involvement remained at the same level (Table 2). We did not observe any statistically significant changes in the occurrence of the misconception that osmosis was related only to water and diffusion to other molecules/gases (Table 2). As in stage 1, the ability to distinguish between diffusion and osmosis depended on being able to correctly define osmosis (Table 3, task 3/5).

An awareness of structures where plasmolysis may occur remained at the same level (Table 1, task 9b). We observed, however, a significant increase (from $30 \%$ in stage 1 to $50 \%$ in stage 2) in the proportion of correct illustrations of the cell placed in solutions in which the water potential differed in relation to the water potential of the cell (Table 1, task 10). Students were significantly less confused about the direction of water flow between solutions (Table 2). This reduction in confusion was probably due to the ability to use the water potential concept in practice and higher awareness of changes in the cell shape that occurred during water flow from the cell (Table 2). Interestingly, the relationship between the ability to apply the water potential concept in practice and the ability to identify accurate illustrations of events occurring in the cell placed in solutions with different water potentials that were apparent before the physiology course was not visible in stage 2 (Table 3 , task 4b/10).

Students' awareness of the association between plasmolysis and osmotic water flow outside the cell increased from $16 \%$ in stage 1 to $32 \%$ in stage 2 , and the increase was statistically significant (Table 1, task 12). Nevertheless, most common 
misconceptions concerning this issue remained unchanged. Students still thought that osmosis and plasmolysis were related to water flow or that both processes had a common goal, that is, to reach equal concentrations (Table 2). Unlike in stage 1, students' understanding of the relationship between osmosis and plasmolysis relied on being able to correctly define osmosis (Table 3, task 3/12). As in stage 1, the ability to identify the link between osmosis and plasmolysis did not result in the correct illustration of events occurring in the cell placed in solutions with different water potentials (Table 3 , task 10/12) or in the awareness of changes in the shape of the cell placed in solutions of different water potentials (Table 3, task 10/12A). Also as in stage 1 , we did not observe any relationship between the ability to indicate structures where osmosis or plasmolysis occurred and the ability to indicate the relationship between osmosis and plasmolysis (Table 3, tasks 9a/12 and 9b/12). The frequency of correct answers concerning the role of the aquaporin in plant cells remained unchanged (Table 2).

\section{Qualitative Analysis of Textbooks}

The high school and university textbooks were analyzed in terms of statements that supported the misconceptions identified above. Because students often neglected to identify the presence of the semipermeable membrane in osmosis $(66 \%$ in stage 1 and 50\% in stage 2) and were not able to properly indicate the kind of particles passing through the membrane $(57 \%$ in stage 1 and $35 \%$ in stage 2), the textbooks' definitions of osmosis were analyzed to identify whether they clearly indicated the presence of a semipermeable membrane in that process and specified the type of particles passing through the membrane. Additionally, we examined whether the textbook definitions 1) supported the idea that osmosis is limited only to water or liquids; 2) promoted the idea that osmosis is a special case of diffusion; or 3) indicated that the tonicity/concentration gradient is the driving force behind osmosis. Because the majority of students were unable to indicate the relationship between osmosis and diffusion (84\% in stage 1 and $68 \%$ in stage 2 ), the textbooks' definitions of plasmolysis were checked as to whether they indicated the cause-effect relationship between the processes. Despite the fact that the plasmolysis process is mandatory in the Polish high school core curriculum, some of the analyzed textbooks did not refer to it, and definitions or descriptions of the process were absent.

The results of the content analysis are summarized in Table 4. Every textbook we analyzed contained or supported at least one misconception identified as widespread among the university students. The results are consistent with findings from previous studies (e.g., Cho et al., 1985; Dikmenli and Cardak, 2004; Deshmukh and Deshmukh, 2011; Kose and Hasenekoglu, 2011). The most common misconception, which occurred in every textbook analyzed, was an indication that osmosis is limited to liquids.

Because the majority of the respondents (60\%) were familiar with aquaporins, we also examined whether textbooks contained a definition of the term. The concept did not occur in any of the five high school textbooks analyzed. It was, however, present in the five of the eight university textbooks. In university textbooks, the information on the structure and function of aquaporins was consistent. The textbooks clearly indicated that aquaporins are proteins that function as "water channels" (five textbooks) or "greatly facilitate the passage of water molecules through the membrane in certain cells" (one textbook).

\section{DISCUSSION}

Processes such as osmosis, diffusion, and plasmolysis are basic concepts in plant physiology. They are present in Poland's middle and high school curricula, and pupils are supposed to be familiar with them. Unfortunately, students find these topics difficult to understand (e.g., Sanger et al., 2001). The results of our studies indicate that university biology students' knowledge about the processes of diffusion, osmosis, and plasmolysis is poor and freighted with many misconceptions.

We observed difficulties in integrating students proper (scientific) knowledge into their general understanding. For example, students who were able to indicate the difference between plasmolysis and osmosis correctly identified structures where plasmolysis occurred, as did students who failed to notice this relationship. Similarly, the drawings of the students who were aware of the relationship between osmosis and plasmolysis included changes in the cell's shape almost as often as students

\section{TABLE 4. Results of textbook content analysis}

\begin{tabular}{|c|c|c|}
\hline Misconception & High school & University \\
\hline Total number of analyzed textbooks & 5 & 8 \\
\hline \multirow[t]{2}{*}{ Number of textbooks containing the definition of osmosis } & 5 & 8 \\
\hline & Number of textbooks containing the misconception related to osmosis & \\
\hline Not mentioning the presence of a semipermeable membrane & 2 & 1 \\
\hline Indication that particles pass through the biological membrane & 1 & 1 \\
\hline Limiting the osmotic process to water molecules only & 3 & 6 \\
\hline Limiting osmotic process to liquids & 5 & 8 \\
\hline Indication that osmosis is a case of diffusion & 1 & 6 \\
\hline $\begin{array}{l}\text { Indication of tonicity or concentration gradient as the driving } \\
\text { force for osmosis }\end{array}$ & 4 & 5 \\
\hline \multirow[t]{2}{*}{ Number of textbooks containing the definition of plasmolysis } & 2 & 8 \\
\hline & Number of textbooks containing the misconception related to osmosis & \\
\hline No indication of the relationship with osmosis & 1 & 7 \\
\hline
\end{tabular}


who were unaware of the association between the two processes.

The concept that caused students the least difficulties was aquaporins. The majority of students (60\%) were familiar with this concept before the plant physiology course. It may seem surprising, since the concept is discussed only in university textbooks; however, during the first and second years of their studies, students participate in courses in which the topic of aquaporins is discussed.

We also observed a statistically significant decrease of several misconceptions after the plant physiology course, especially in the ability to define osmosis and distinguish between diffusion and osmosis. Significantly more students were aware that osmosis occurs in the presence of a semipermeable membrane and indicated correctly the type of particles taking part in the process (water or solvent). The proportion of answers indicating that the difference between osmosis and diffusion is associated with the direction of flow in relation to the concentration gradient significantly decreased, which suggests that more students recognized the spontaneity of both processes. A statistically significant increase was also observed in students' ability to correctly illustrate cell behavior in solutions with different water potential. Students more frequently indicated the correct direction of water flow and changes in cell shape. We believe that this improvement was due to the possibility of directly observing the cell behavior during plasmolysis under the microscope and an improved ability to use the water potential concept in practice, since a significant increase in the proportion of the correct answers concerning particle movement in the context of water potential was also observed. Still, the frequency of occurrence of most misconceptions remained unchanged, which is, perhaps, not surprising, since they are extremely difficult to correct during the traditional process of education, a fact that is well documented in the literature (Winer et al., 2002; Bahar, 2003; Chi, 2013).

It is worth noting, however, that plant physiology courses include not only lectures but also laboratory practice, which might be assumed to be more effective than a traditional lecture. We suggest that students performing laboratory experiments are often unaware of the scientific ideas behind them. This observation is consistent with other research results present in the literature, suggesting the low effectiveness of practical work in supporting conceptual understanding of research findings (see Abrahams and Millar, 2008; Abrahams and Reiss, 2012). In students' minds, the link between theory and practice, that is, between what they read and what they do in the laboratory, seems to be poor at this point. Bearing this fact in mind, it may be assumed that many students see textbooks as the most reliable sources of knowledge concerning osmosis and plasmolysis. The fact that many of the textbooks support students' misconceptions makes attempting conceptual change even more difficult. Another serious obstacle to promoting conceptual change may be a low involvement of the learner in terms of being an active player in the process of knowledge restructuring (Sinatra and Pintrich, 2003). Our observations indicate that plants, in general, are not appreciated by students, and we find a description of "plant blindness" in the literature (Wandersee and Schussler, 1999).

Teachers need to be aware of findings such as ours and employ appropriate strategies. Planning and teaching any subject is a complex cognitive activity that requires not only content knowledge but also pedagogical, social, and other skills. Teachers with differentiated and integrated pedagogic understanding will have a greater ability to design and carry out lessons that will help students develop deep understanding of a concept (Magnusson et al., 1999). As Bednar and coauthors (1992) state, when designing a teaching process it is not so important to implement some particular theory of learning. The authors promote the idea that developers (teachers) need to be aware of their personal beliefs about the nature of learning and select concepts and strategies consistent with their beliefs. One of the major assumptions of constructivism is that knowledge evolves through social negotiation and through the evaluation of the viability of individual understanding (Savery and Duffy, 1995). Dewey's "linking science" (Bednar et al., 1992) has to be introduced into regular teaching practice at university level. We assume that what is missing from the traditional laboratory is a collaborative group that can discuss, reconstruct conceptions, and test their own understanding of particular issues or phenomena during the learning process.

What is alarming is the fact that some misconceptions, such as the belief that osmosis and plasmolysis are unrelated or the conviction that osmosis is a typically biological process, dominate the scientific conceptions. The vast majority of our students are also unable to distinguish between diffusion and osmosis, which suggests that the source of such misconceptions may be the way that students are introduced to these phenomena. Indeed, definitions of osmosis in high schools and university textbooks may promote or even strengthen widespread miscomprehension. Among five osmosis definitions presented in high school textbooks, two did not mention the presence of the semipermeable membrane, thus enhancing the confusion between diffusion and osmosis. Another textbook indicates that, during osmosis, molecules pass through the "biological membrane," which promotes the conviction that osmosis is typically a biological process. Moreover, three out of five textbook definitions indicated that water is the only type of molecule involved in osmosis, and only two of them defined molecules passing through the membrane as solvent molecules, thus creating a misconception that osmosis refers only to water, which is what $27 \%$ of students thought before taking the university plant physiology course. All analyzed textbook definitions limited osmosis to liquids, which-according to Hershey's classification of misconceptions-is an undergeneralization (Hershey, 2004, 2005), since osmosis also applies to gases (Kramer and Myers, 2012). One of the university textbooks explained that osmosis is a case of diffusion, which is an obsolete theory (Kramer and Myers, 2012). In four of the five high school textbooks, osmosis is described in the context of tonicity or concentration. Only one showed osmosis in the context of water potential, which may explain the lack of knowledge of the concept before the plant physiology course.

In four of the five high school textbooks, osmosis was defined in the context of tonicity or concentration gradient, which is an oversimplification, since the gradient of hydrostatic pressure plays an equally important role in regulating osmotic flow as the solute concentration (Kramer and Myers, 2013). Moreover, we analyzed eight university textbooks and found 
that all eight definitions defined osmosis as a phenomenon limited to liquids, while six indicated water was the only compound involved in the process. In addition, six textbooks described osmosis as diffusion through a semipermeable membrane, and one did not mention that the process occurs in the presence of the semipermeable membrane. Another textbook stated that the process occurs through the "biological membrane." Only one university textbook stated that osmosis is a physical not a biological process. Five university textbooks presented osmosis in the context of the concentration gradient and one in the context of tonicity. Only three of them referred to water potential. Although $90 \%$ of respondents indicated that they had become familiar with plasmolysis at an earlier (preuniversity) stage of education, the topic was mentioned in only two of the five school textbooks, and in only one case was it reported as the result of the osmotic flow of water from the cell. All the university textbooks contained a definition of plasmolysis. However, most of them described plasmolysis as the separation of cytoplasm from the cell wall as the result of water loss. Only one of them clearly mentioned the fact that plasmolysis occurs as an effect of osmotic flow. It can be assumed that the lack of direct embedding of plasmolysis in the context of osmosis makes it difficult for students to link the two phenomena.

We conclude that the vast majority of osmosis definitions found in both high school and university textbooks include misconceptions that correspond with those widespread among university students. They belong mainly to categories of misconceptions described as "undergeneralization" and "obsolete theory" (Hershey, 2004, 2005). To limit the confusion related to osmosis, we recommend a more interdisciplinary approach to the issue in biology textbooks. The fact that osmosis is a physical not a biological process should be highlighted, and the definition of osmosis should be reformulated following Kramer and Myers's (2012) notion that "osmosis is the flow of solvent across a semipermeable membrane from a region of lower to higher solute concentration." In the course of discussing osmosis, the types and properties of solutions should be recalled, with an emphasis on solvent definition and its physical states, that is, not only liquid but also gas and solid (Averill, 2012).

Misconceptions concerning plasmolysis result mainly from students' fragmentary knowledge and their difficulties in integrating it into their own conceptual overview. Our conclusion is that in both high school and university textbooks the causeand-effect relationship between osmosis and plasmolysis could be emphasized more strongly.

Texts that are not free from mistakes, misconceptions, or understatements might serve didactical purposes. According to Posner et al. (1982), the major goal of teaching and learning in the process of conceptual change is to create cognitive conflict to make learners feel dissatisfied with their existing conceptions. The scientific conception has to be intelligible, plausible, and fruitful in order to serve as a new one for the learner and to lead to successful conceptual change. These conditions are often difficult to meet, particularly when teaching large classes.

We recommend introducing into regular seminars or even lectures a method based on the constructivist theory of learning that is called "questioning the author" (QtA; Beck et al., 1996; Beck and McKeown, 2006). QtA was designed to facilitate student interactions with text and build greater understanding by teaching students to question the ideas presented while they are reading (Beck and McKeown, 2002, 2006). At first, the method was used with younger students who, according to Beck and McKeown (2001), are able to handle a challenging content. QtA involves the teacher stopping at predetermined points in a text or in a classroom discussion and asking open-ended questions. It has been used at higher levels of education, for example, in the project ETOS, which was designed to support science teaching and learning in primary schools (years 4-6) and junior secondary schools (years 1-3; Basińska et al., 2012). In the project, QtA was mostly used as a technique for modeling classroom discussions and analyzing scientific animations. It was also introduced at high school and university levels (Rybska and Basińska, 2014). The opening questions that usually start the discussion are "What is this all about?" and "What do you think?" This method allows students to use their own language. Teachers use the students' words to reinforce the correct part of their answers or to discuss with them what the concept could be if this incorrect conception appeared in real life.

QtA seems to be an alternative to teacher-oriented classroom conversations, facilitating collaborative learning and discourse. Osborne (2010) writes that collaborative learning provides opportunities for students to engage in discourse and argumentation as a means of enhancing students' conceptual understanding, skills, and capabilities for scientific reasoning. As one of the "ideal" hallmarks of the scientist is critical and rational scepticism, the lack of opportunities to develop the ability to reason and argue scientifically would appear to be a significant weakness in contemporary educational practices. In short, knowing what is wrong matters as much as knowing what is right. There is a limitation in introducing the QtA method, as it requires university teachers to become familiar with it and to be willing to implement it into their regular teaching activities. Applying the QtA method on a regular basis might allow teachers to become familiar with students' preexisting knowledge and offer students an opportunity to ask and seek answers and-what is even more importantgive them the right to be wrong, because every conception is discussed in depth.

\section{CONCLUSION}

Students' misconceptions are extremely difficult to change during the traditional course comprising lectures and practical exercises. Our finding is consistent with previous research concerning conceptual change (see Bahar, 2003). In our opinion, it is important to apply specific didactical methods, for example, QtA, when teaching about water relations in plant cells, because it enables continuous monitoring of students' current knowledge so as to help them acquire a more scientific understanding of particular concepts.

\section{ACKNOWLEDGMENTS}

We thank Prof. Justin Dillon for his suggestions and kind review of the manuscript. 


\section{REFERENCES}

Abrahams I, Millar R (2008). Does practical work really work? A study of the effectiveness of practical work as a teaching and learning method in school science. Int J Sci Educ 30, 1945-1969.

Abrahams I, Reiss MJ (2012). Practical work: its effectiveness in primary and secondary schools in England. J Res Sci Teach 49, 1035-1055.

Averill BA (2012). Solutions. In: Principles of General Chemistry, version 1.0, chap 13. http://2012books.lardbucket.org/books/principles-of-general -chemistry-v1.0/index.html (accessed 20 June 2014).

Bahar M (2003). Misconceptions in biology education and conceptual change strategies. Educ Sci 3, 55-64.

Basińska A, Pietrala D, Cole R, Dziubalska-Kołaczyk K (2012). ETOS-innowacyjne narzędzie wspomagające nauczanie i uczenie się przedmiotów przyrodniczych. Studia edukacyjne 23/2012, 229-248.

Beck IL, McKeown MG (2001). Text talk: capturing the benefits of read-aloud experiences for young children. Read Teach 55, 10-20.

Beck IL, McKeown MG (2002). Questioning the author: making sense of social studies. Educ Leadersh 59, 44-47.

Beck IL, McKeown MG (2006). Improving Comprehension with Questioning the Author: A Fresh and Expanded View of a Powerful Approach, New York: Scholastic.

Beck IL, McKeown MG, Sandora C, Kucan L, Worthy J (1996). Questioning the Author: a yearlong classroom implementation to engage students with text. Elem Sch J 96, 385-414.

Bednar AK, Cunningham D, Duffy TM, Perry JD (1992). Theory into practice: how do we link. In: Constructivism and the Technology of Instruction: A Conversation, ed. TM Duffy and DH Jonassen, Hillsdale, NJ: Erlbaum, 17-34.

Bluman AG (2009). Elementary Statistics: A Step by Step Approach, 7th ed., New York: McGraw-Hill Humanities.

Chi MTH (2013). Two kinds and four sub-types of misconceived knowledge ways to change it, and the learning outcomes. In: International Handbook of Research on Conceptual Change, 2nd ed., ed. S Vosniadou, New York: Psychology Press, 49-70.

Chi MTH, Roscoe RD (2002). The processes and challenges of conceptual change. In: Reconsidering Conceptual Change: Issues in Theory and Practice, ed. M Limon and L Mason, Dordrecht, Netherlands: Kluwer Academic, 3-27.

Cho HH, Kahle JB, Nordland FH (1985). An investigation of high school biology textbooks as sources of misconceptions and difficulties in genetics and some suggestions for teaching genetics. Sci Educ 69, 707-719.

Creswell JW (1994). Research Design Qualitative and Quantitative Approaches, Thousand Oaks, CA: Sage.

Deshmukh N, Deshmukh V (2011). Textbook: a source of misconceptions at the secondary school level. In: Proceedings of epiSTEME 4-International Conference to Review Research on Science, Technology and Mathematics Education, ed. S Chunawala and M Kharatmal, Mumbai, India: Macmillan, 144-149.

Dikmenli M (2010). Misconceptions of cell division held by student teachers in biology: a drawing analysis. Sci Res Essay 5, 235-247.

Dikmenli M, Cardak O (2004). A study on misconceptions in the 9th grade high school biology textbooks. Eurasian J Educ Res 17, 130-141.

Driver R (1989). Students' conceptions and the learning of science. Int J Sci Educ 11, 481-490

Edling A (2006). Abstraction and authority in textbooks: the textual paths towards specialized language. Doctoral dissertation, Uppsala, Sweden: Uppsala University. http://uu.diva-portal.org/smash/record.jsf?pid=diva2 :168583 (accessed 15 June 2014)

Freedman JC, Sperelakis N (2012). Diffusion and permeability. In: Cell Physiology Source Book, 4th ed., ed. N Sperelakis, San Diego, CA: Academic, 113-120.

Friedler Y, Amir R, Tamir P (1987). High school students' difficulties in understanding osmosis. Int J Sci Educ 9, 541-551.

Glaser BG, Strauss AL (1967). The Discovery of Grounded Theory: Strategies for Qualitative Research, Chicago, IL: Aldine.

Hershey DR (2004). Avoid misconceptions when teaching about plants www.actionbioscience.org/education/hershey.html (accessed 20 June 2014).
Hershey DR (2005). More misconceptions to avoid when teaching about plants. www.actionbioscience.org/education/hershey3.html (accessed 20 June 2014)

Hsieh HF, Shannon SE (2005). Three approaches to qualitative content analysis. Qual Health Res 15, 1277-1288.

Huck SW (2008). Inferences on percentages, proportions, and frequencies In: Reading Statistics and Research, Boston: Pearson Education, 404 434.

Johansson I, Karlsson M, Johanson U, Larsson C, Kjellbom P (2000). The role of aquaporins in cellular and whole plant water balance. Biochim Biophys Acta $1465,324-342$

Kaid LL (1989). Content analysis. In: Measurement of Communication Behavior, ed. P Emmert and LL Barker, New York: Longman, 197-217.

Kose EO, Hasenekoglu I (2011). Misconceptions and alternative concepts in biology textbooks: nucleic acids and protein synthesis. Energy Educ Sci Technol B 3, 403-410.

Kramer EM, Myers DR (2012). Five popular misconceptions about osmosis Am J Phys 80, 694-699.

Kramer EM, Myers DR (2013). Osmosis is not driven by water dilution. Trends Plant Sci 18, 195-197.

Krippendorff K (1989). Content analysis. In: International Encyclopedia of Communication, ed. E Barnouw, G Gerbner, W Schramm, TL Worth, and L Gross, New York: Oxford University Press, 1, 403-407. http:// repository.upenn.edu/asc_papers/226 (accessed 28 May 2014).

Magnusson S, Krajcik J, Borko H (1999). Nature, sources, and development of pedagogical content knowledge for science teaching. In: Examining Pedagogical Content Knowledge, Dordrecht, Netherlands: Springer 95-132.

Meir E, Perry J, Stal D, Maruca S, Klopfer E (2005). How effective are simulated molecular-level experiments for teaching diffusion and osmosis? Cell Biol Educ 4, 235-248.

Minorsky PV (2008). Resource acquisition and transport in vascular plants. In Biology, 8th ed., ed. NA Campbell and JB Reece, San Francisco: Pearson, 764-784.

Mintzes JJ, Wandersee JH, Novak JD (1998). Epilogue: meaningful learning, knowledge restructuring and conceptual change: on ways of teaching science for understanding. In: Teaching Science for Understanding, San Diego, CA: Academic, 327-350

Mintzes JJ, Wandersee JH, Novak JD (2005). Teaching Science for Understanding: A human Constructivist View, San Diego, CA: Academic.

Odom AL (1995). Secondary and college biology students' misconceptions about diffusion and osmosis. Am Biol Teach 57, 409-415.

Odom AL, Barrow LH (1995). Development and application of a two-tier diagnostic test measuring college biology students' understanding of diffusion and osmosis after a course of instruction. J Res Sci Teach 32 45-61.

Odom AL, Kelly PV (2001). Integrating concept mapping and the learning cycle to teach diffusion and osmosis concepts to high school biology students. Sci Educ 85, 615-635.

Osborne $J$ (2010). Arguing to learn in science: the role of collaborative critical discourse. Science 328, 463-466

Özmen H (2004). Some student misconceptions in chemistry: a literature review of chemical bonding. J Sci Educ Technol 13, 147-159.

Pfundt H, Duit R (2004). Bibliography: Students' Alternative Frameworks and Science Education, Kiel, Germany: University of Kiel Institute for Science Education.

Posner GJ, Strike KA, Hewson PW, Gertzog WA (1982). Accommodation of a scientific conception: toward a theory of conceptual change. Sci Educ 66, 211-227.

Rundgren CJ, Chang SN, Schönborn KJ (2010). Students' conceptions of water transport. J Biol Educ 44, 129-135.

Rybska E, Basińska A (2014). Dialog, który ma wartość edukacyjną. O metodzie Questioning the Author. Edukacja Biologiczna i środowiskowa 4/2014, 34-40

Sanger MJ, Brecheisen DM, Hynek BM (2001). Can computer animations affect college biology students' conceptions about diffusion and osmosis? Am Biol Teach 63, 104-109. 
Savery JR, Duffy TM (1995). Problem based learning: an instructional model and its constructivist framework. Educ Technol 35, 31-38.

She HC (2004). Facilitating changes in ninth grade students' understanding of dissolution and diffusion through DSLM instruction. Res Sci Educ 34, 503-525.

Sinatra GM, Pintrich PR (2003). Preface. In: Intentional Conceptual Change, ed. GM Sinatra and PR Pintrich, London: Lawrence Erlbaum Associates, $5-10$.

Smith J III, Disessa A, Roschelle J (1994). Misconceptions reconceived: a constructivist analysis of knowledge in transition. J Learn Sci 3, 115163.

Stangroom J (2014a). Social Science Statistics: Chi-Square Calculator. www .socscistatistics.com/tests/chisquare/Default2.aspx (accessed 6 July 2014).
Stangroom J (2014b). Social Science Statistics: Z Score Calculator for 2 Population Proportions. www.socscistatistics.com/tests/ztest/Default2.aspx (accessed 8 July 2014).

Tomažič I, Vidic T (2012). Future science teachers' understanding of diffusion and osmosis concepts. J Biol Educ 46, 66-71.

Wandersee JH, Mintzes JJ, Novak D (1994). Research on alternative conceptions in science. In: Handbook of Research on Science Teaching and Learning, ed. DL Gabel, New York: Macmillan, 177-210.

Wandersee JH, Schussler EE (1999). Preventing plant blindness. Am Biol Teach 65, 82-86.

Winer GA, Cottrell JE, Gregg V, Fournier JS, Bica LA (2002). Fundamentally misunderstanding visual perception: adults belief in visual emissions. Am Psych 57, 417-424. 